\title{
Islamic Economics: The State of the Art
}

\author{
Muhammad Akram Khan
}

\begin{abstract}
This paper reviews the development of Islamic economics at various levels. It examines the discursive accumulation of knowledge on Islamic economic topics and explores their contents and future direction. It evaluates the achievements of research and banking institutions. It also examines the extent to which Islamic economics has gained acceptance in the minds of ordinary Muslims and in the practices of Muslim states. This review is intended to provide a roadmap for the future development of the discipline. In the spirit of constructive critical thinking it also provides a useful critique of the many failures of the institutions and limits of the discourse.
\end{abstract}

\section{Introduction}

This paper like an earlier endeavor, ${ }^{1}$ seeks to assess the state of Islamic economics today. The objective is to make a fair evaluation of the achievements and challenges of Islamic economics as a discipline and to make a few suggestions for future course of action.

Islamic economics in the contemporary era started developing just after World War II when a large number of Muslim countries got independence from colonial rule. There had always been a smoldering flame in the psyche of the Ummah to reincarnate its bygone glory. Independence from colonial rule only kindled this flame revealing a sudden large-scale awakening to the need for developing Islamic disciplines. People in these formerly colonized countries had always desired to fashion their lives and institutions according to the Islamic worldview. Islamic economics emerged as one of the foremost fields toward this end. During colonial rule, economic institutions underwent a massive change, offending the Muslim 
sensibilities, primarily due to the introduction of interest in the economy. In addition, the colonial rulers discarded the system of zakah to which the Muslims looked as a safety valve against unforeseen calamities and mass poverty.

The early efforts toward Islamic economics were restatements of the Islamic teachings relating to economics as mentioned in the Qur'an, Hadith, and figh. Most of its contributors were religious scholars with very little exposure to modem concepts of economics. But their efforts did bear fruit. In 1976, at the First International Conference on Islamic Economics, over 200 economists, scholars, and social scientists from all over the world assembled in Makkah. This watershed conference exposed the participants to the growing need to address the concepts of Islamic economics at a more professional level and encouraged professional economists to make serious contributions.

\section{Achievements}

From its humble beginnings over two decades ago, Islamic economics has grown as an academic discipline. There are quite a few successes that no one can ignore.

I shall mention them by way of example, in the absence of any comprehensive database on these issues:

An independent discipline

Islamic economics is now a serious academic discipline, evident from the number of books and articles being published on the subject. Presently, there are twelve journals, some of them refereed, exclusively devoted to Islamic economics. This is over and above a large number of Islamic journals that publish material relating to it. In addition, journals of conventional economics, management, business studies, and accounting also publish material related to Islamic economics. One of the significant developments is that Palgraves Dictionary of Money and Finance ${ }^{2}$ now includes an article on Islamic banking.

Intellectual efforts

During the last two decades, a number of bibliographies have come out. Starting with M.N. Siddiqi's Bibliography and Survey of the Literature in 1976, a number of volumes have appeared which list literature on the subject. For example, the Islamic Research and Training Institute (IRTI), Jeddah, published a comprehensive bibliography in 1993 and Tariqullah 
Khan's bibliography of 1984. S. Nazim Ali published a bibliography in 1994, and Javed Ahmad Khan in 1995. In addition, the Centre for Research in Islamic Economics (CRIE), Jeddah, published a series of bibliographies on specialized topics. I published two volumes of annotated bibliographies in 1983 and 1989. A third one is pending publication, and I am working on a fourth volume. These bibliographies speak for the academic activity going on in the field.

\section{University courses}

Islamic economics also occupies a place in the academic courses of various universities and colleges. International Islamic University Malaysia and International Institute of Islamic Economics in Islamabad, offer degree courses in Islamic economics. Several universities in Pakistan, Iran, Sudan, Saudi Arabia, and other Islamic countries offer courses on Islamic economics as part of a regular degree progam in economics. This is in addition to those which take up subjects relating to Islamic economics as an additional area of study. Loughborough University in Leicester (UK) offers a program in Islamic economics. Also, International Institute of Islamic Economics and Insurance in London offers a diploma course through correspondence. Other Islamic economics correspondence courses are offered on the Internet.

\section{Ph.D. dissertations}

A large number of universities accept research projects leading to a Ph.D. in economics with subjects related to Islamic economics. I have copied from the Internet the abstracts of forty-seven Ph.D. dissertations accepted by various U.S. universities from 1953 to 1996 . I could not lay my hands on information from other universities. Incidentally, this type of information should be gathered at one of the Islamic economics research centers.

\section{Islamic economics research centers}

There are at least four research centers or institutes exclusively devoted to Islamic economics. Of these, Islamic Research and Training Institute under the Islamic Development Bank, Jeddah, deserves special mention. It has an in-house team of professionals and commissions research studies from outside as well. Until 1997, it had published 180 books and monograms on Islamic economics.

The International Institute of Islamic Thought, a U.S. based think tank too has made important contributions to the development of Islamic economic thought. It has organized a large number of professional seminars, 
academic workshops, and meetings in various places. Proceedings of seven of these meetings have already been published. IIIT has published fourteen books on the topic in English and forty-four books in Arabic. The institute is now undertaking a research project on the "Intellectual Map of Islamic Economics." The purpose of this project is to identify and describe the contemporary intellectual scene in the field of Islamic economics, in terms of its academic literature and institutional practices so that directions and priorities for new research can be identified. IIIT also copublishes the American Journal of Islamic Social Sciences with the Association of Muslim Social Scientists. Over the years, the journal has published two special issues dedicated to Islamic economics and dozens of articles on the subject.

\section{Islamic economics databases}

The Islamic Development Bank has also developed a database on Islamic banking, finance, and economics. The bank has five databases: Islamic Banks Information System (Arabic and English), Islamic Economics Bibliography, Islamic Economics Bibliography (Index), Muslim Experts Information System, and Directory of Channels of Communications (directory of addresses and other communication means among Islamic financial institutions).

\section{Compendiums of Shari'ah studies}

The Fiqh Academy of the Organization of Islamic Countries, the Fiqh Academy of India, the Islamic Ideology Council of Pakistan, and the Association of Islamic Banks have published valuable material relating to the Shari'ah position on various contemporary issues relating to economics, business, and finance. The Ministry of Religious Affairs and Awqaf of Kuwait has so far published thirty-seven volumes of Encyclopaedia of Fiqh. The work is still going on. The Encyclopaedia contains a large number of entries about subjects relevant to Islamic economics. The Institute of Islamic Banking and Insurance, London, in addition to publishing the Encyclopaedia of Islamic Banking and Insurance, has recently brought out the Encyclopaedia on Shari'ah Rulings on Islamic Banking and Finance (1998). The Urdu Encyclopaedia of Islam published by Punjab University, Lahore, contains several entries on subjects relating to Islamic economics. The Turkish Encyclopaedia of Islam published in Istanbul also includes entries relating to Islamic economics. 


\section{Accounting and auditing standards}

On a more technical side, the Islamic financial institutions have set up a board for developing accounting and auditing standards relating to Islamic banks. The board has created the Accounting and Auditing Organization for Islamic Financial Institutions (AAOIFI) in Bahrain. This organization consists of highly skilled people within the profession who have started issuing accounting standards relating to Islamic banks and financial institutions. One volume delineating these standards came out in 1994. In 1997, it was revised and expanded to include several new topics. The Institute of Islamic Banking and Insurance, London, has also issued a book on accounting of Islamic banks. These efforts reveal a growing interest among academicians and practitioners in subjects relating to Islamic economics.

\section{Professional body}

There also exists a professional body of Muslim economists under the name of International Association of Islamic Economics. The Association, though not very active, publishes a professional journal besides organizing occasional conferences and seminars.

\section{Conferences and seminars}

Every year scores of conferences, seminars, and symposia are held around the world which are either exclusively devoted to Islamic economic themes or are related to issues in Islamic economics.

\section{Internet}

If we surf the Internet we find a large number of entries regarding Islamic economics, Islamic banking, and related subjects. Some individuals and associations - such as Islamic Development Bank, International Islamic University Malaysia, The Islamic Foundation of Leicester, and the International Institute of Islamic Banking and Insurance, London - have also made serious research work available on the Internet without charge. There are also announcements regarding various courses and training programs in Islamic economics.

\section{Islamic banking and finance}

All this has come in the wake of the practical implementation of Islamic economics. The most significant development has been in the field of Islamic banks. At present, more than 100 Islamic banks, managing funds worth $\$ 80$ billion operate in thirty-three countries. This includes a number of specialized financial institutions like mudaraba companies, ijara companies, takafol companies, and unit trusts. The Islamic Development Bank, 
Jeddah operates as a leader in this field. Pakistan, Iran, and Sudan claim to have Islamized their entire financial system, although we have our reservations about such claims. In Malaysia, under the patronage of its central bank, an Islamic capital market with a number of innovative financial instruments is emerging. The Islamic financial institutions have introduced a large number of new financial products. Though these developments have their weaker points, it shows a growing interest in the Islamic economic and financial system. It is also evidence of the growing influence of Islamic economics in actual life.

Zakah systems

Pakistan, Sudan, Saudi Arabia, Kuwait, and Malaysia have introduced systems of zakah. They have brought in new legislature or modified an earlier one and created administrative structures to manage the zakah funds.

\section{Shortcomings}

After counting the achievements of Islamic economics, we now turn to its shortcomings.

\section{Narrow focus}

The focus of Islamic economics has been on a very narrow range of subjects. Most of the researchers and scholars have written on Islamic banking and finance or zakah to the neglect of other areas. For example, Javed Ahmad Khan's bibliography (1995) has 1,621 entries, 936 of which pertain to interest and zakah. To an uninitiated reader, it gives the impression that Islamic economics is primarily concerned with interest-free banking and zakah. Even when these two subjects are the focus, the research is extremely limited, leaving out fundamental questions. For example, there are very few studies that discuss, in a rigorous and conclusive manner, the negative effects of interest, although data on developed capitalist economies are available, and it should be possible to show that this institution is a source of injustice for humanity. Similarly, as we shall argue subsequently, the discussions relating to zakah are based on outdated fiqh premises, which cannot withstand scrutiny.

Islamic economics removed from real life

Islamic economics is still an adjunct of the main economic courses based on conventional secular economics. First, the subjects covered in conventional economics are too wide to be ignored. Second, the growth in secular economics is related to real life issues, and it is difficult to remain oblivi- 
ous of it. Herein lies the real weakness of Islamic economics. Islamic economics does not concern itself with real life. Except for the literature on Islamic banking and finance that has mushroomed in the last few years, the literature is only theory, not related to the real-life situation in the society. An extreme example of this is that Muslim economists have not focused on Muslim societies, claiming that these societies are secular and not Islamic.

The fact is that Muslim societies, however removed they may be from the Islamic ideal, still retain some Islamic values. People still lead life according to Islam, if not ideally, at least to some extent. Islamic economics could study the behavior of the people in these societies and then analyze the extent to which that behavior was influenced by Islamic values; it could also study how this behavior could be transformed into Islamic norms. Waiting for the ideal Islamic society to manifest is like waiting for doomsday. If Islamic economics makes the study of existing Muslim societies its subject, it will enrich itself considerably, and its relevance to real life will increase tremendously.

\section{Confusion about the methodology}

There still exists some confusion about the methodology of Islamic economics. First, some economists who were trained in the West have become fascinated with Islamic economics. They think that Islamic economics is secular economics with some verses of the Qur'an or a few hadith sprinkled in. They neither appreciate the reason why Islamic economics is being developed nor the way in which the worldview of Islam changes the researcher's outlook. Second, many researchers have not been able to firm up their response to conventional economics. Muslim economists are shy to enter into a dialogue with conventional economists. Another academic discipline needs to be developed because of the difference in worldviews. This difference is likely to affect theories, postulates, hypotheses, and laws of economics as developed in the West. Therefore, the Muslim economists should be engaged, in most cases, in examining the work published in conventional economics, pointing out the similarities and differences between the two disciplines. They should go theory by theory, postulate by postulate, hypothesis by hypothesis, and institution by institution, discussing the position of Islamic economics on each one of them. It means an appropriate research approach will yield a critique of Western economics backed up by a large body of literature. One reason that Islamic economics has not moved in this direction could be that Muslim economists, who are themselves trained in conventional economics, do not find themselves equal to 
the challenge. It requires a very deep understanding of the two worldviews and years of patient thinking to undertake such a venture. Obviously, most Muslim economists have not been trained for this type of innovative work.

Talking to one another

Muslim economists are talking to one another. The jargon, the style, the level of argument being used presumes a Muslim audience. Of course, Muslims are the first audience of this discipline. But Islamic economics should be developed as a discipline for all human beings. Muslim economists should address humanity at large. If they adopt this approach, the agenda for research, the level of argument, the terminology, and the style of discussion will undergo a change. At present, most of the writings on Islamic economics do not make much sense to the ordinary educated person. It does not mean that Islamic economics should not use technical terms or should live with the secular economics terminology; rather, it means the subjects of research should be more general in nature. The argument presumes faith in Islamic values and belief in Islam. It makes the frame of discussion for Muslims only. If we look at the style of the Qur'an, it addresses humanity at large, not only Muslims. This approach would make Islamic economics more comprehensible and interesting for ordinary educated Muslims as well as non-Muslims.

Absence of consensus on basics

Islamic economics has not developed a core of basic principles. Although most contributors have written on the basic principles, they have done so without going into the details of real-life application. Some examples will illustrate this point.

\section{(a) Alternatives to interest}

There seems to be a consensus that the alternative to interest-based financing is profit-loss sharing or a variant thereof. But in practice, the Islamic banks and financial institutions do not find profit-loss sharing a realistic alternative. They fear the dishonesty of their clients or are apprehensive of the monitoring cost. Moreover, bankers must have developed and diversified skills to play an active role in a profit-sharing proposition that protects the interest of the depositors. As a result, profit-loss sharing cannot become a going concern. Islamic banks adopted various techniques that brought them a fixed return; for an ordinary person, it is very similar to interest-based financing. Despite the rationalization, Islamic economists have been unable to convince the ordinary person that the alternatives 
adopted by Islamic banks are Islamic in nature. The entire enterprise of Islamic banking has become a doubtful proposition, more devoted to literalist or legalistic solutions, satisfying theologians but not yielding any benefit to humanity. Muslim economists have not accepted this criticism. The situation is so unbearable that certain Islamic research institutes or centers have produced a great deal of literature on Islamic banking without listening to the arguments of the other side. It seems the attitude is: We do not care what you say; we are sure of our own righteousness. This attitude needs reconsideration because it is one of the obstacles to persuading ordinary people about the veracity of the concepts of Islamic banking. In fact, the type of Islamization that took place in Pakistan, for example, has evoked more ridicule than praise.

(b) Inflation and interest

Another example is the question of inflation and interest. In those countries where the rate of inflation is high, it is difficult to make people accept a zero rate of return on savings, because it is tantamount to accepting a lower real value over time. Despite the faith in the prohibition of riba, people feel that those who save will get a bad deal at the hands of the Shariah in an inflationary economy. Islamic economists have not been able to find a solution to this problem. All suggestions about indexation have met with rejection, but no alternative has been offered.

(c) Role of government

Economists have given every shade of opinion on the role of government — from all-pervading to minimal — and have brought arguments in their support from the primary sources of Islamic law or history. An unwary reader of the literature remains unsure of the Islamic position.

(d) The law of zakah

The questions relating to rate, nisab, types of wealth, or income subject to zakah contain several ambiguities and differences of opinion. The discussion is so involved that at the end of the day, one is not sure about Islam's position. As a corollary to this is the Islamic position on taxation; opinions differ as to whether any tax other than zakah is acceptable.

(e) Land tenancy

The question of the land tenancy system remains as open as it has been throughout Islamic history. No innovative work has emerged that could settle the position of Islam on this vital question. 


\section{(f) Justice and benevolence}

Muslim economists and Shari'ah scholars agree that the Islamic economic system is based on the concepts of justice and benevolence (' $\mathrm{adl}$ and ihsan). But the definition of justice is not agreed upon. The dimensions of justice and benevolence and how to achieve them are not clear. The entire literature on the subject is devoid of any effort to operationalize these basic concepts. As a result, these two concepts have become mere slogans.

These are merely two examples; a comprehensive list of such issues could also be drawn.

Intellectual freedom

Islamic economic institutions and centers of research are hardly places of free intellectual activity. Governments or other influential people who finance them like to keep these organizations within the constraints of "defined freedom of thinking." This approach definitely stifles innovative intellectual work, repulsing free-thinking minds. Moreover, the scholars of Islamic economics seem to be afraid of the grip of the clergy, from whom they fear severe opposition. They feel shy of suggesting innovative ideas, despite all the talk of ijtihad.

\section{Professional body}

Another example of a stillborn organization is the International Association of Islamic Economics. This body, which could have bloomed into a professional association for consolidating knowledge and soliciting consensus on various issues, has done little except host some seminars and irregularly publish a journal. It has not even been able to attract a majority of Muslim economists, let alone invite non-Muslim economists to participate in its activities. In Muslim countries, university faculties have not even heard of the association. The reasons for such inertia should be explored. Suffice it to say that Muslim economists are losing a great opportunity and a potential forum.

\section{The Hope}

The above discussion should not depress Muslim economists. There are many developments taking place that augur well for the development of Islamic economics. Muslim economists should treat them as opportunities and make a contribution. We shall give a few examples. 


\section{Human resource development}

In recent years, there has been a growing concern in the world for human resource development. The annual publication of the UN's Human Development Report and the changes occurring in the economic literature and research agenda are welcome changes from the Islamic point of view. In fact, Islamic economics approaches the entire subject of economics from a human angle. Conventional economists were late to realize the importance of human resource development; however, it is a positive development.

\section{Unbalanced development}

A lot of literature in economics is now addressing the question of "unbalanced development." The conventional development theory is based on an unbalanced concern for material betterment to the neglect of the environment and distribution of income and equity among the people. Now these concerns are being addressed. From the Islamic perspective, this is a desirable change.

\section{Privatization}

The recent surge toward privatization, coupled with a regulatory mechanism to protect the public interest, is very much a concept that Islamic economics supports. Once again economic theory is recognizing something that Islamic economics upheld centuries ago in the form of a free market regulated by the institution of al-hisba.

Foreign direct investment

A growing trend in international capital movement favors foreign direct investment (FDI) over debt capital. For example:

Inflow of FDI into developing countries have surged from $\$ 31$ billion in 1990 to $\$ 80$ billion in 1993 , almost $60 \%$ of it going to Asia. The entire outflow of investment since 1990 has reduced the rich world's capital stock by a mere $0.5 \%$ from what it would otherwise have been. ${ }^{2}$

This shows that the world has recognized the role of enterprise and realized the need for preferring it to debt capital. By itself, it is a welcome trend from the Islamic point of view.

Venture capital

There is a new trend in the developed countries toward venture capital. The financiers have started providing capital to new ventures with bright 
business propositions on the basis of equity rather than as a loan on interest. In its spirit, the concept is closer to the Islamic concept that favors enterprise rather than interest. In this regard, some data relating to the United States will be of interest. In the United States,

in 1984, there were 600 venture capital firms with a total of 6 billion dollars invested ... According to the latest research, the so-called "angel money" represents the largest source of venture capital in the US. Business "angels" are those invisible individual investors who provide small amounts of equity capital to the startup and development of companies. According to Wetzel, there are about 250,000 business angels in the US, with a venture portfolio totaling at least 25 billion dollars. He further estimates that the portfolio will soon reach 100 billion dollars. Moreover, these investors provide each year, $\$ 10$ to $\$ 20$ billion to between 50,000 and 100,000 firms. $^{3}$

\section{Workers as partners}

The Islamic view of workers as partners is now being applied by many progressive businesses. Several methods for involving workers in the management of firms have been devised. Two examples are: Employee Stock Ownership Plans (ESOPs) and membership of workers on the firm's board of directors. The effectiveness of the ESOPs in the U.S. is indicated by the fact that in 1988 , more than 10 million workers and 10 thousand companies were covered by them, figures that represent increases, over a ten-year period, of 260 percent and 150 percent respectively. Current research shows that these methods are highly beneficial for both firms and employees. Productivity has increased, workers are happier at their workplace, and customer satisfaction has improved. ${ }^{4}$

\section{Voluntary sector}

There is an upsurge of the voluntary sector in the world. The voluntary sector concept is embedded in the Islamic concept that human beings are both selfish as well as altruistic and that Islam promotes altruism without ignoring self-interest. Gradually humanity is realizing the truth of this concept. In most developed countries, as well as in developing countries, voluntary organizations are coming up for philanthropic work. For example in Japan, by 1985 , some 2 million voluntary welfare workers - housewives as well as retired husbands - had registered with municipal centers. By 1995 , their number had swollen to over 5 million. Today, some 64,000 vol- 
untary groups have been established across Japan. Even so, there are still proportionately only a tenth as many volunteers in Japan as in America.

Public debt

It is pertinent to note that the world has finally recognized that the public debt is a curse and that it is leading to misery, poverty, and exploitation of the poor countries at a massive scale. A flood of literature is coming out, pleading for some mechanism to redeem humanity from the tyranny of interest. The atmosphere for arguing the case of Islamic economics has never been as favorable as it is today.

\section{Corruption}

We can see a sudden uproar against corruption in the developing countries and the role being played by the developed countries in promoting and protecting corruption. All over the world there is a strong realization that corruption, in all its forms, must come to an end. A few decades ago, corruption was not an issue. But now a large number of pressure groups, appropriate legislation, and institutions are coming up all over the world to fight this menace. I wish Muslims had founded organizations like Transparency International. This is a welcome opportunity for Islamic economics to demonstrate its potential for humanity.

\section{Civil society}

Corruption cannot be fought by legislation or the creation of institutions only; there is a dire need for creating a "civil society." In general, "civil society" means that people are mobilized to stand up and fight corruption at all levels. They are organized to blow the whistle, put up resistance against corrupt elements, and help the government in fighting it. If we think deeply about these ideas, they are nothing but the Islamic concept of enjoining the proper and forbidding the improper behavior (amr bi al-maruf wa nahi 'an al-munkar). Islamic economics has not employed this concept appropriately. It is time to do so.

These are but a few examples; a more comprehensive list could be drawn of non-Muslim economic ideas and concepts that are drawing close to Islamic concepts. These ideas show that humanity is moving toward the ultimate truth revealed by the divine message that came through the prophets of Allah. Islamic economics cannot take credit for the trend that is moving the world toward its own ideas and concepts. Humanity has reached this point through much experimentation and rational thinking. But these concepts show that Islamic economics has a very favorable time. 
Humanity is already disposed favorably toward what Islamic economics is pleading for. It is necessary that the presentation of Islamic economics should be more persuasive, based on rational thinking, real-life data, and convincing arguments. The real challenge is in proper presentation and formulation of the concepts and postulates of Islamic economics. I do not think there would be much resistance from the world at large if we succeed in doing so.

\section{The Future}

Now we turn to the last question in this paper: What should be the strategy of Muslim economists, scholars, and institutions toward developing Islamic economics for the future?

\section{Intellectual resources}

The Ummah needs to develop its intellectual resources for the Islamization of knowledge. The Qur'an, Hadith, fiqh, and Islamic history should be examined so that material relevant to Islamic economics is classified, annotated, explained, and published in stand-alone volumes. This rich heritage of the Ummah is still inaccessible to Western-trained economists and scholars. As a result, they rely on secondary sources. Innovative thinking is inversely proportional to the availability of original sources. Thus, if we want Western-trained scholars to contribute, we must make a concerted effort to make our primary sources accessible to them. This requires publishing anthologies of material sifted from the Hadith, fiqh, history, and social life along with proper indexing and research tools. These sources should also be made widely accessible over the Internet for greater access.

\section{Expansion in scope}

Islamic economics needs to widen the scope of its research. Two major breakthroughs are essential: First, it should study the real conditions of Muslim societies and relate them to Islamic economics, even though these societies are far from the Islamic ideal. This will provide a rich agenda for future research and help Muslim economists contribute toward the transformation of these societies. Second, the Muslim economists need to grab the opportunity being offered to them by the overall intellectual environment. As argued above, there are several currents and crosscurrents in economics that are quite near to the Islamic point of view. We need avail ourselves of this opportunity and examine these currents in detail. It should 
then lead us to identify any fine differences between contemporary thinking and the pristine Islamic approach. These developments will enrich Islamic economics and fertilize its ideas.

\section{Critique of "secular" economics}

Muslim economists must undertake the essential task of critically examining the developments in "secular" economics. Their research agenda should include reviewing all secular economic issues and stating the Islamic economic position. It means we should take up all Western economic knowledge concept by concept, theory by theory, and institution by institution and show how Islamic economics differs or agrees with it. This will immediately cause Islamic economic knowledge to increase many times.

\section{Institutionalize consensus building}

Much of the criticism leveled at Islamic economics relating to its inability to create a consensus is valid. There has been no systematic effort to create institutions to establish the basic postulates. In "secular" sciences, professional bodies engage in this type of activity. Although Islamic economics does have an International Association of Islamic Economics, its role is mostly decorative. It has long been dormant. It is time that the Ummah create dynamic institutions that can define a process for arriving at consensus. Let me add here that the classical concept of consensus, where everyone agrees, does not hold here. We have to accept the concept of majority rule, leaving the door open for dissenting opinions to flourish on their own. Islamic economics should be able to publish a set of basic postulates that have the support of the majority of the scholars. This requires a massive effort but is important for further development of the discipline.

\section{Opinion building and marketing}

Islamic economics also suffers from poor projection. Although it has a natural lobby of over a billion people who support it merely because it has the sanction of Islam, Muslim economists are unable to make their voices heard. Even in Muslim societies, the ordinary educated person is skeptical of its viability; educational institutions have not included its basic principles in their programs; the policy-making bodies are unaware what promise Islamic economics holds for them; and the bureaucrats often ridicule it. There is a need to propagate Islamic economic teachings. The universities should hold seminars, meetings, and conferences to increase awareness. ${ }^{5}$ 
Fight for the independence of thought

Muslim economists should encourage independent thinking and allow difference of opinion. Islamic economics should not be afraid of dissenting opinion. The divine message has the strength to withstand all human criticism. The process of criticism is a sure road to the development of knowledge. Muslim economists should fight for preserving the right of others to disagree, even though this right is exercised to criticize Islamic economics. In fact, Muslim economists should make available anthologies of literature criticizing Islamic economics. These books should be taught in university courses as well, and students should be encouraged to examine them independently.

\section{Human welfare}

In the final analysis, Islamic economics should concentrate on the problems of human welfare. No matter how grotesque our arguments and how persuasive our intellectual architecture, if we are unable to contribute toward the welfare of humanity, we will not be able to survive. We must widen our audience to include all of mankind. Our Prophet was sent to address the whole of humanity. Alas! We have (inadvertently) restricted His message to Muslims only. Let us change the focus once again. We must address human problems and humanity at large. Support will follow automatically.

\section{Notes}

1. See Toward Islamization of Disciplines (Herndon, VA: The International Institute of Islamic Thought, 1989), 273-294.

2. Palgraves Dictionary of Money and Finance (London: Macmillan, 1992).

3. Venture Capital Journal, September 1986: 3.

4. J.W. Henry, "ESOPs with Productivity Payoffs," Journal of Business Strategy, July-August 1989: 33.

5. One good effort made by the International Institute of Islamic Economics, Islamabad, was a training program for the senior officers of banks and financial institutions. The objective of the program was to inform the senior personnel in these institutions about Islamic economic teachings. Alas! Even this has been abandoned. 